\title{
LINHA DE FRENTE
}

\section{Linha d'Água n.21}

Este número inicia-se com a entrevista à $\operatorname{Prof}^{\mathrm{a}}$. Dr ${ }^{\mathrm{a}}$. Maria Vicentina de Paula do Amaral Dick, Membro da Comissão Permanente de Licenciatura da Universidade de São Paulo. A Professora participa de discussões no âmbito nacional, o que lhe permite compreender o quadro brasileiro quanto aos licenciados ou aos que se encontram em processo de licenciatura.

Os artigos direcionam-se à pesquisa e ao ensino e discutem questões voltadas à língua portuguesa, ao ensino fundamental, médio e superior. Localiza-se discussão em torno do livro didático e discute-se a edição na imprensa de São Paulo.

O Ensaio tem por temática língua e sociedade e o Diário de Classe traz o posicionamento do professor frente à leitura e à produção escrita.

Clássicos estrangeiros, como Humbold e Daudet, são motivo do que se apresenta na Tradução e em um dos Artigos.

A Resenha trata da avaliação da linguagem e o Relato refere-se ao Encontro da Associação de Professores de Língua e Literatura (APLL) que transcorreu na USP e que reunião, professores dos diversos níveis de ensino, além de estudantes.

Na seção de Inéditos, localizam-se textos poéticos.

São Paulo, agosto de 2008.

Equipe Editorial 